\title{
INTRALINGUAL TRANSLATION: A SIMPLIFIED VERSION OF THE ORIGINAL NOVEL DAVID COPPERFIELD
}

\author{
Fani Hafizah, Syahron Lubis, Muhizar Muchtar \\ Universitas Sumatera Utara, Medan, Indonesia \\ E-mail: fanihafizah18@gmail.com
}

Received: 08 August2020;

Accepted: 27 November 2020

\begin{abstract}
The objectives of this project are to describe the intralingual translation techniques used in translating the original novel David Copperfield into a simplified version and to find out the reasons why the translator made a simplified version of the original novel David Copperfield written by Charles Dickens. This study used the descriptive qualitative method. The data were collected by reading the novel, comparing the original and simplified texts of David Copperfield, identifying, classifying, counting, and concluding the results. The theory of Jakobson was used to analyze the data related to intralingual translation techniques. The results of the study showed that from the total data (20 texts from the original novel David Copperfield and 20 texts from the simplified version), the paraphrasing technique was used 6 times and the summarizing technique was used 14 times. Besides, the most dominant intralingual translation technique used by the translator is the summarizing technique. The reasons why the translator used paraphrasing and summarizing techniques in making the intralingual translation of the original novel into a simplified version were also found. Firstly, the original novel consists of 750 pages, which are easier to read by making the summary of the novel into 238 pages using the summarizing technique. Secondly, the original novel consists of many difficult words, which can hinder the comprehension of the reader whereas in the simplified version the novel was paraphrased by using the paraphrasing technique.
\end{abstract}

Keywords: intralingual translation, summarizing, paraphrasing.

\section{Introduction}

Translation is a process where a translator translates material from the source language to the target language. In translating a text, a translator has to find the equivalent meaning to the context and culture (Hatim, 2004). Newmark (as cited in Machali, 1998) defines translation as a craft consisting of attempts to replace a written message and statement in one language with that same message and statement in another language.

Jakobson (1959) in his article breaks down the theory of translation into three areas, namely the intralingual translation, which refers to rewording or paraphrasing, summarizing, and ending or commenting within a language; the interlingual translation, which covers the same process as previous, but from one language into another ("translation proper"); and the intersemiotic translation or transfer of signs from one language to non-verbal sign system ("transmutation"). He further uses the expression "intralingual transposition" in his discussion of poetry and the linguistic aspects of translating poetry. 
Intralingual Translation: A Simplified Version of The Original Novel David Copperfield, Fani Hafizah, Syahron Lubis, Muhizar Muchtar

Based on the aforementioned definition of intralingual translation, the researchers are interested to analyze the paraphrasing and summarizing techniques in doing the intralingual translation by using Jakobson's theory. David Copperfield is a novel written by Charles Dickens in 1850. The classic version of David Copperfield has a difficult structure to understand. For this reason, the original novel and the simplified version of David Copperfield were compared to find out the techniques used in doing the intralingual translation.

\section{Literature Review}

Translation has an important role in language (Catford, 1965). Nida and Taber (1969) state that translating consists of reproducing the receptor language with the closest natural equivalent of the source language message, firstly in terms of meaning and secondly in terms of style. Both definitions above imply that translation involves two languages, the source language (SL) and the target or receptor language ( $T L$ or $\mathrm{RL}$ ). Therefore, an act of translating is an act of reproducing the meaning from the SL text to the TL text (Baker, 1992).

The area of paraphrasing and summarizing was also specified by Jakobson (1959) as follows.

1) Paraphrasing is a restatement of the meaning of a text or passage using other words. $A$ paraphrase usually gives an explanation or clarification of the text that is paraphrased. It can be a useful technique for readers as well as it helps them easily understand the meaning of a certain phrase.

For example:

Giraffes like Acacia leaves and hay, and they can consume 75 pounds of food a day. (Original Text)

A giraffe can eat up to 75 pounds of acacia leave and hay daily. (Paraphrasing Text)

2) Summarizing is reducing the text to one-third or one-quarter its original size by clearly articulating the author's meaning and retaining main ideas. The purpose of summarizing is to briefly present the key points of a theory or work to provide context for your argument/thesis.

For example:

"The Northern Lights"

There are times when the night sky glows with bands of color. The bands maybegin as cloud shapes and then spread into a great arc across the entire sky. They may fall in folds like a curtain drawn across the heavens. The lights usually grow brighter, then suddenly dim. During this time, the sky glows with pale yellow, pink, green, violet, blue, and red. These lights are called the Aurora Borealis. Some people call them the Northern Lights. Scientists have been watching them for hundreds of years. They are not quite sure what causes them. In ancient times people were afraid of the lights. They imagined that they saw fiery dragons in the sky. Some even concluded that the heavens were on fire. (Original Text)

The Northern Lights, also known as the Aurora Borealis, are bands of color in the night sky. Ancient people thought that these lights were dragons on fire and even modern scientists are not sure what they are. (Summarizing Text) 


\section{Research Method}

This research employed the qualitative descriptive method. A case study to describe the translation techniques used in doing the intralingual translation of the original novel David Copperfield was analyzed using Jakobson's theory. In this research, the data were collected in the form of texts from the original novel David Copperfield written by Charles Dickens and the simplified version written by Malvina G. Vogel. The original novel consists of 750 pages while the simplified version consists of 238 pages. The steps in analyzing the data were 1) reading the novel, both the original and simplified versions to identify the equivalence; 2 ) comparing both versions to analyze the techniques used in making the intralingual translation; 3) finding out the suitable translation techniques after analyzing the target texts by using some aspects, namely total words, word changes, synonyms, and deletions; and4) writing down the table to classify the collected data and give explanations.

\section{Results and Discussion}

Table 1: Intralingual Translation Technique Classification

\begin{tabular}{|l|l|l|}
\hline No. & Technique & Frequency \\
\hline 1 & Paraphrasing & 6 \\
\hline 2 & Summarizing & 14 \\
\hline \multicolumn{2}{|l}{ Total Data } & 20 \\
\hline
\end{tabular}

After collecting 20 texts from both original and simplified versions of David Copperfield, the analysis of the intralingual translation techniques was done by identifying some aspects as indicators. It was found that the most dominant technique used in the intralingual translation of the original novel David Copperfield written by Charles Dickens is the summarizing technique. The technique was used 14 times as seen from the data above.

\subsection{Paraphrasing Technique}

Paraphrasing usually aims at preserving the essential meaning of the material that is being translated and paraphrased. It means that the reinterpretation of a source that gives a different meaning to the original statement goes into the category of original research and not paraphrase. Paraphrasing can be considered a translation technique. It is proved that it is a useful tool for translators and writers and it helps improve the quality of the text.

Table 2: Analysis of Paraphrasing Technique

\begin{tabular}{|c|l|l|l|l|l|l|l|}
\hline No. & $\begin{array}{c}\text { Page/ } \\
\text { Total } \\
\text { Words }\end{array}$ & Source Text & Target Text & Translation & \multicolumn{3}{|c|}{ Aspect } \\
\cline { 5 - 7 } & & $\begin{array}{l}\text { Technique } \\
\text { Change }\end{array}$ & Synonym & Deletion \\
\hline 1 & $1,7 /$ & $\begin{array}{l}\text { I was born } \\
\text { (as I have } \\
\text { been } \\
\text { informed and } \\
\text { believe) on } \\
\text { Friday, at } \\
\text { twelve }\end{array}$ & $\begin{array}{l}\text { I was born } \\
\text { on Friday at } \\
\text { twelve } \\
\text { o'clock at } \\
\text { night. The } \\
\text { clock began } \\
\text { to strike and }\end{array}$ & Paraphrasing & - & $\begin{array}{l}\text { simultane } \\
\text { ously > at } \\
\text { the same } \\
\text { time }\end{array}$ & $\begin{array}{l}\text { I was born } \\
\text { fas I have } \\
\text { been } \\
\text { informed } \\
\text { and believe) } \\
\text { on Friday, at } \\
\text { twelve }\end{array}$ \\
\hline
\end{tabular}


Intralingual Translation: A Simplified Version of The Original Novel David Copperfield, Fani Hafizah, Syahron Lubis, Muhizar Muchtar

\begin{tabular}{|l|l|l|l|l|l|}
\hline & $\begin{array}{l}\text { o'clock at } \\
\text { night. It was } \\
\text { remarked } \\
\text { that the clock } \\
\text { began to } \\
\text { strike, and I } \\
\text { began to cry, } \\
\text { simultaneous } \\
\text { cry at the } \\
\text { same time }\end{array}$ & & & & \\
& & & & & $\begin{array}{l}\text { o'clock at } \\
\text { night. It was } \\
\text { remarked } \\
\text { that the } \\
\text { clock began } \\
\text { to strike, } \\
\text { and I began } \\
\text { to cry } \\
\text { simultaneou } \\
\text { sly. }\end{array}$ \\
\hline
\end{tabular}

Table 2 shows that the translator used the paraphrasing technique to simplify the original text (source text) into the target text. Two aspects supported the paraphrasing technique, namely the synonym and deletion. The translator put the synonym of the word "simultaneously" into "at the same time" from the original into the simplified one. The second aspect, the translator also deleted the sentence within the brackets to make it easier to understand.

\subsection{Summarizing Technique}

The purpose of summarizing is to present the key points of a theory or work to provide context for your argument. Summarizing is useful in many types of writing and at different points in the writing process. Summarizing is used to support an argument, provide context for a paper's thesis, write literature reviews, and annotate a bibliography.

Table 3: Analysis of Summarizing Technique

\begin{tabular}{|c|c|c|c|c|c|c|c|}
\hline \multirow[b]{2}{*}{ No. } & \multirow[b]{2}{*}{$\begin{array}{c}\text { Page/ } \\
\text { Total } \\
\text { Words }\end{array}$} & \multirow[b]{2}{*}{$\begin{array}{l}\text { Source } \\
\text { Text }\end{array}$} & \multirow[b]{2}{*}{ Target Text } & \multirow[b]{2}{*}{$\begin{array}{l}\text { Translation } \\
\text { Technique }\end{array}$} & \multicolumn{3}{|c|}{ Aspect } \\
\hline & & & & & $\begin{array}{l}\text { Word } \\
\text { Change }\end{array}$ & Synonym & Deletion \\
\hline 1 & $\begin{array}{l}7,1 / \\
53,25\end{array}$ & $\begin{array}{l}\text { My mother, } \\
\text { I say, was } \\
\text { sitting by } \\
\text { the fire, } \\
\text { that bright, } \\
\text { windy } \\
\text { March } \\
\text { afternoon, } \\
\text { very timid } \\
\text { and sad, } \\
\text { and very } \\
\text { doubtful of } \\
\text { ever } \\
\text { coming } \\
\text { alive out of } \\
\text { the trial } \\
\text { that was } \\
\text { before her, } \\
\text { when, } \\
\text { lifting her } \\
\text { eyes as she } \\
\text { dried them }\end{array}$ & $\begin{array}{l}\text { Earlier that } \\
\text { afternoon } \\
\text { my mother } \\
\text { had been } \\
\text { sitting by } \\
\text { the fire } \\
\text { feeling } \\
\text { timid and } \\
\text { sad and she } \\
\text { saw a } \\
\text { strange } \\
\text { lady } \\
\text { coming up } \\
\text { the garden } \\
\text { path. }\end{array}$ & Summarizing & $\begin{array}{l}\text { windy } \\
\text { March } \\
\text { afternoon > } \\
\text { earlier that } \\
\text { afternoon } \\
\text { was sitting } \\
>\text { had been } \\
\text { sitting }\end{array}$ & - & $\begin{array}{l}\text { My } \\
\text { mother, I } \\
\text { say, was } \\
\text { sitting by } \\
\text { the fire, } \\
\text { that bright, } \\
\text { windy } \\
\text { March } \\
\text { afternoon, } \\
\text { very timid } \\
\text { and sad, } \\
\text { andvery } \\
\text { doubtulof } \\
\text { ever } \\
\text { coming } \\
\text { alive-out of } \\
\text { thetrial } \\
\text { thatwas } \\
\text { before her, } \\
\text { len, } \\
\text { lifting hef } \\
\text { eyesas she }\end{array}$ \\
\hline
\end{tabular}




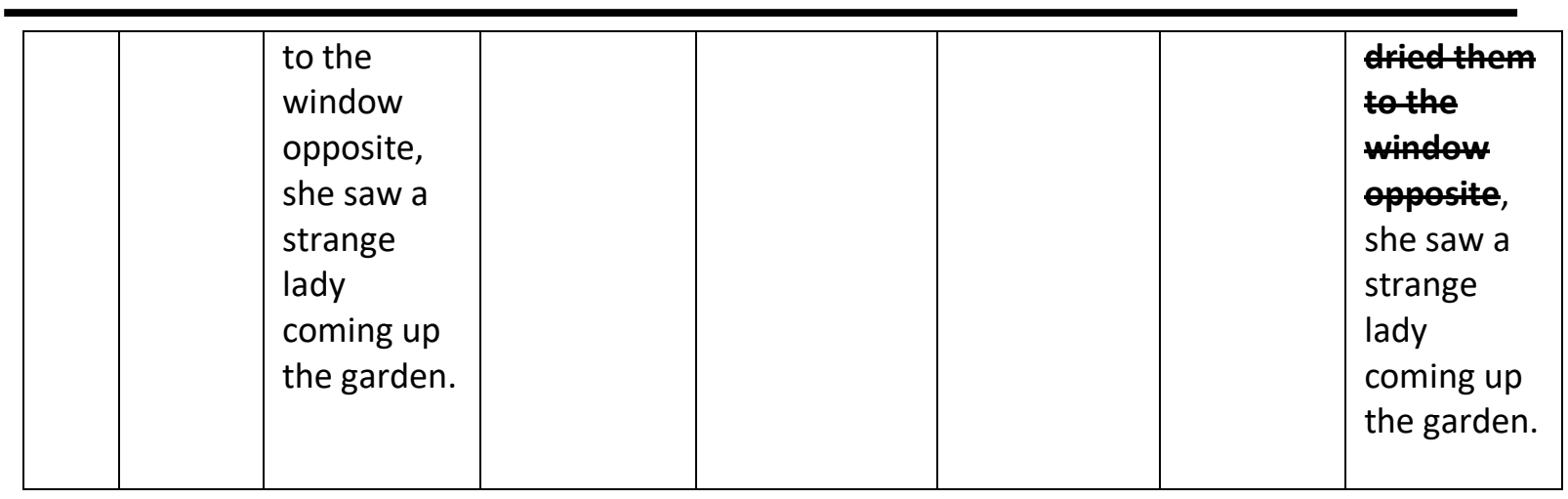

From Table 3, it was shown that the translator used the summarizing technique because many deletions happened in the simplified version to simplify the main idea of the original text. The translator summarized the original text from 54 words to 26 words to make it easier to read. The translator also changed some difficult words into common ones to make it understandable, for example, "windy March afternoon" became "earlier afternoon".

\section{Conclusion}

The techniques usually used in doing the intralingual translation are paraphrasing and summarizing, so the researchers worked with these techniques to analyze the data of the novel. Based on the research findings. The total data comprised 40 texts. 20 texts were taken from the original novel David Copperfield by Charles Dickens and 20 texts from the simplified version by Malvina G. Vogel. There were two techniques in total and from 20 texts, the paraphrasing technique was used 6 times while the summarizing technique was used 14 times. Consequently, the dominant intralingual translation technique used by the translator is the summarizing technique.

The researchers also found two reasons why the translator used the paraphrasing and summarizing techniques in doing the intralingual translation. They are:

1. The original novel David Copperfield consists of 750 pages. It is easier to read the novel by making the summary of it into 238 pages using the summarizing technique; and

2. The original novel David Copperfield consists of many words that are hard to understand. Changing the difficult words into common ones using the paraphrasing technique can make readers understand the novel easily.

\section{References}

Baker, M. (1992). In other words: A Course Book on Translation. London: Routledge. Catford, J. C. (1965). A linguistic Theory of Translation. London: Oxford University Press. Hatim, B. A. (2004). Translation: An Advanced Resource Book. London: Routledge. Jakobson, R. (1959). On linguistic Aspects of Translation. In L. Venuti, The translation studies reader (pp. 113-118). London: Routledge.

Machali, R. (1998). Redefining Textual Equivalence in Translation. Jakarta: Faculty of Letters UI.

Newmark, P. (1988). A textbook of Translation. Hong Kong: Pearson Education Limited.

Nida, E., \& C, Taber. (1969). The Theory and Practice of Translation. Leiden: United Bible Societies. 